\title{
1 INDIGENOUS PLACENAMES: AN INTRODUCTION
}

\author{
Luise Hercus and Jane Simpson
}

\section{INTRODUCTION ${ }^{1}$}

In Australia we have two sets of placenames, one superimposed over the other. These are the set of networks of placenames that Indigenous Australians developed to refer to places (the Indigenous placename networks), and the set of placenames that Europeans developed to refer to places (the introduced placename system). The placenames bestowed by Europeans have been systematically recorded and they form the bulk of the official placenames of Australia, ranging from names for houses, streets and dams, to names for States and the country itself. Indigenous placenames, on the other hand, have been sporadically recorded by Europeans, varying in accuracy of reproduction of sound, meaning and even referent; there are many examples of Europeans recording words of the ordinary language, thinking that they were placenames (but see Hercus's paper in this volume for apparently 'silly' names that are likely to have been genuine placenames).

The ways of forming Indigenous placenames, their meanings, the features that they refer to, the networks that they form, and the rights to bestowal of names differ greatly from European toponymic practices. These differences in toponymy caused much confusion to European settlers, and, as Paul Carter (1988:61-68) argues, reinforced beliefs that Aborigines had different views of places, and thus of ownership of places.

\footnotetext{
This paper owes a great deal to conversations with David Nash and Harold Koch, neither of whom, however, is responsible for our conclusions. We are also grateful for valuable comments from the audiences at the Second Workshop on Australian Languages, University of Melbourne, 20 December 1997; the AUSTRALEX conference, University of Queensland, 17 July 1998; the Australian Placenames of Indigenous Origin: Interdisciplinary Colloquium, the South Australian Geographical Names Committee Premises, Adelaide, 9 April 2000, and The Australian National University, Linguistics Department Seminar, 17 April 2000.

We use the following conventions for typestyle of placenames of words of Indigenous languages. When a placename in a spelling that is no longer current is discussed as a name, it is given in italics. When a placename in the modern spelling of an Indigenous language is discussed as a name, it is given in italic bold. When a placename is discussed as a place, it is given in plain typestyle. Words of Indigenous languages in modern spelling are given in bold. Words of Indigenous languages in a spelling that is no longer current are given in italics. Glosses for meanings of placenames are given in single inverted commas.
}

L. Hercus, F. Hodges and J. Simpson, eds, The Land is a Map: placenames of Indigenous origin in Australia, 1-23. Canberra: Pandanus Books for Pacific Linguistics, 2002. 
Within Indigenous toponymic practices there is much variation, depending both on society and on environment. The papers in this volume attempt to address the variation within Indigenous toponymic practices, as well as other issues of toponymy, including documenting, assigning and reinstating Indigenous placenames. In this introductory paper we outline some of these issues, and we contrast the Indigenous practices with the introduced practices.

The earliest recorded Indigenous placenames are over 40 names recorded as placenames in the Sydney area (Troy 1994). One of those that Troy lists, Parramatta, is unequivocally an Indigenous placename that has been taken into the introduced system. ${ }^{2}$ Such incorporation of Indigenous placenames into the official introduced placenames set has been sporadic, as Monaghan (this volume) points out. The surveyor Thomas Mitchell's preference for Indigenous placenames is well known, and contrasts with some other explorers (but see Carter (1988:67) for discussion of his motives for using them). Later writers sometimes also expressed the desire to use Indigenous placenames. For example, Edward Stephens (1889:498) wrote in an essay on Aborigines:

In conclusion I express the hope that young Australia, instead of reproducing the names of all the counties, towns, hamlets, mountains, lakes, and rivers of Europe and Asia, will preserve the names which the aborigines of Australia gave to the distinctive features of their ancient home.

More recently, in 1986, in a speech at the Second National Nomenclature Conference Dorothy Tunbridge urged the importance of documenting the Indigenous placename networks, and of establishing an official body that would actively and systematically record Indigenous placenames, and also of reinstating the Indigenous placenames (Tunbridge 1987).

In the nineteenth century a few people recorded Indigenous placenames, perhaps the most extensive being the many Diyari names recorded by Reuther and Hillier in northern South Australia which Philip Jones's paper discusses. A few of these were taken into the introduced placename set, especially in remote areas. But the desire of the colonists to honour friends and benefactors and commemorate loved places proved very strong in many areas, and resulted in the loss of many Indigenous placenames. In the twentieth century, anthropologists and linguists started recording Indigenous placenames more systematically. Among them are the 1,100 names recorded by T.G.H. Strehlow for Arrernte country in Central Australia (Strehlow 1971), and the many names recorded by Norman Tindale. A table of about 50 such projects recording places and Indigenous names is given in Henderson and Nash (1997). This table excludes many of the tens of thousands of Indigenous placenames that have been documented and mapped as a result of heritage and sacred site surveys, land claims under the Aboriginal Land Rights (Northern Territory) Act 1976, and more recently of Native Title claims (Henderson and Nash 2002, Sutton, this volume). However, the documentation is rarely published, for practical and legal reasons, including the unresolved issue of Indigenous intellectual property. It lies in the offices of land councils and government departments.

Some of the projects mentioned by Henderson and Nash have resulted in publication of Indigenous placenames, for example Berndt et al. (1993) have nine maps with more than 300 placenames in the Lake Alexandrina-Coorong area of South Australia, and Dixon (1991) lists about 165 Yidiny placenames from north Queensland. A dictionary of 4,700 placenames officially recognised in the introduced placename system was published in 1992 (Appleton \&

\footnotetext{
2 The restriction 'recorded as placenames' is important, because, while many other places in the Sydney area have names from Indigenous languages, we do not know if they were Indigenous placenames for the same area.
} 
Appleton 1992). About a third of the placenames in it came from Indigenous languages (Henderson and Nash 1997).

In 1993 a traineeship was funded at the Australian Institute of Aboriginal and Torres Strait Islander Studies (AIATSIS) for an Indigenous person to compile a national Indigenous placenames dictionary. The project proved too large for one person, but the final report provided some useful suggestions on investigating Indigenous placenames (Edwards c.1996). Another step towards documenting the Indigenous placename networks was taken in 1998 with the establishment of the National Place-names Project (since January 2000, the Australian National Placenames Survey), coordinated by one of the editors of this volume, Flavia Hodges, who helped organise the two placenames workshops that provided the impetus for this publication.

Documenting placenames takes several forms, depending in large part on how much the introduced placename system has replaced the Indigenous placename networks, that is, on how well the Indigenous placename networks have survived the invasion. In some areas, such as parts of Central and Western Australia, Arnhem Land and Cape York, the transmission of Indigenous placenames is unbroken. The owners of the placenames have been able to maintain their language and their residence on or near the land concerned. In such cases anthropologists, linguists and cartographers can work with speakers to get very rich data on placenames. These include not only the exact extent and location of the named feature, but also an understanding of placenames as systems of mnemonics for identifying places, and as integral to a group's understanding of its history, culture, rights and responsibilities for land. In this volume, Peter Sutton's paper describes such work among peoples living on Cape York, and Patrick McConvell does so for Gurindji people of the Victoria River area.

Another aspect of documentation of existing Indigenous placename networks concerns the use of placenames in societies. Basso (1996) shows the importance of placenames in everyday conversation in American Apache society, as mnemonics for moral tales, and Walsh (1997) and Merlan (2001) have taken this up for northern Australian societies. In this volume, Franca Tamisari discusses the culturally shared notions and images that placenames evoke for several Yirritja and Dhuwa groups in Arnhem Land, how the names both embody and provoke discussion of people's relationships with the land, and how this all relates to the words used for talking about naming. Similar themes are taken up by Baker (this volume) for the Ngalakgan, and by Wilkins (this volume) for the Arrernte of Central Australia. Wilkins also highlights the significance of vocabulary for talking about place and country.

In Arnhem Land, Central Australia and Cape York we can still see the unbroken transmission of the placename networks, and of the meanings associated with them, and we can see the diversity of toponymic practice. However, all Indigenous placename networks are under threat, and, when memories are fading, it is particularly urgent that the networks should be at least recorded. 


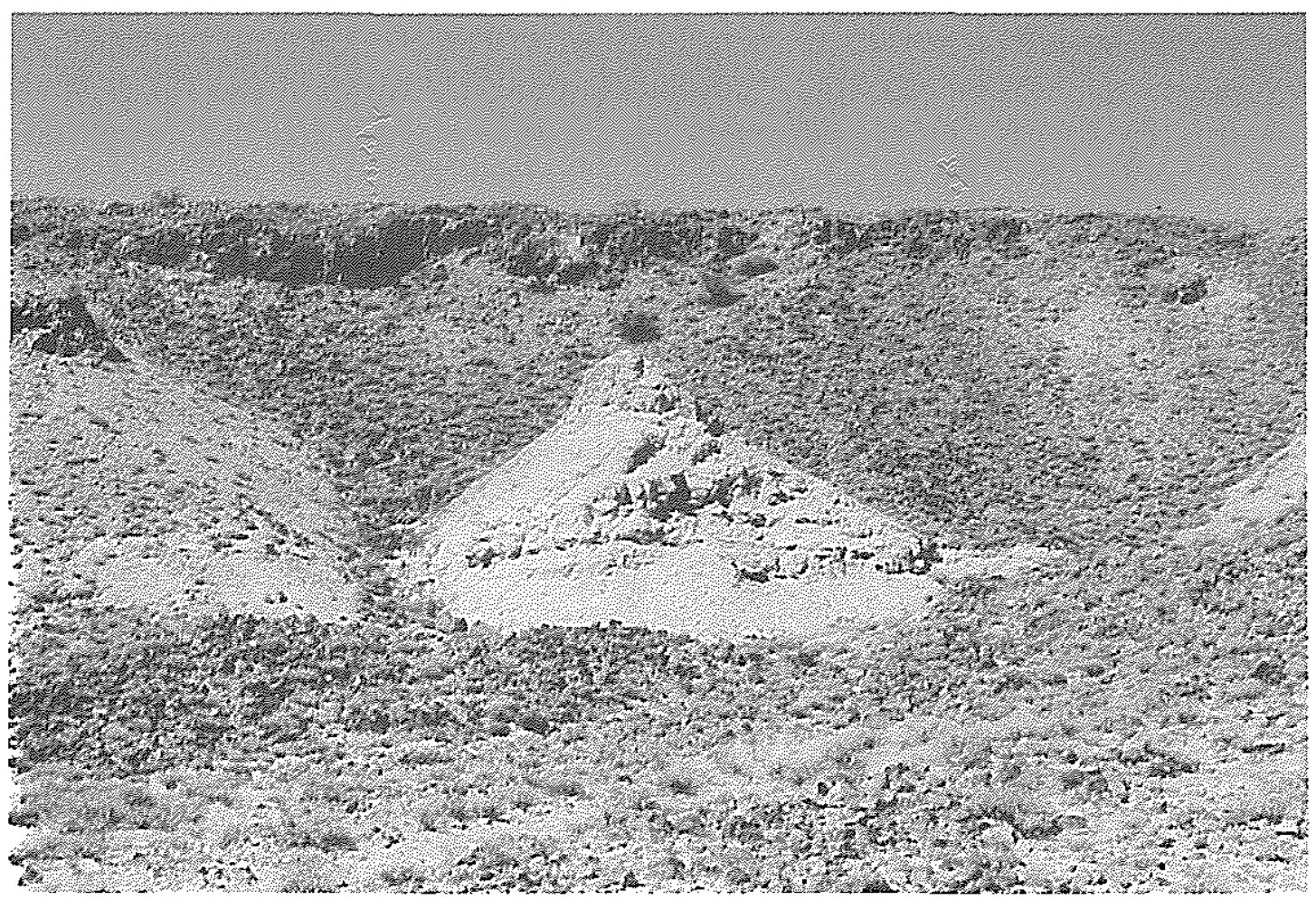

Figure 1: Alhalkere. He is there, all painted up trying to get up to the top of the rise. Photo: C. Macdonald

An example that illustrates what is likely to be lost, and thus the urgency for recording information on placenames, comes from spectacular 'break-away' country in traditional Lower Southern Arrernte country. The site Alhalkere, the Arandic word for 'nosepeg', is not named on maps. It is in the general location of Eternity Dam which is to be found on the 1:100 000 Alinerta sheet, which is part of the 1:250 000 Dalhousie map sheet in South Australia on the Northern Territory border (594850E 7064650N, Dalhousie SG 53-11). It is a piece of 'break-away', a conical hill that has split away from the main rocky range. It represents the 'erotic old man Thudnungkurla', and is the final site for a long, now almost forgotten myth of travel through Kuyani, Arabana and Lower Southern Arrernte country. After many nuptial adventures - always involving two women - this Ancestor arrives at a women's site on the Macumba. He is involved with 'a multitude' of women and is so worn out that he just manages to crawl over the sandhills until he comes to the hills near Eternity Dam. He knows the end is near and puts on his ceremonial gear including his nosepeg. As he tries to climb to the top he dies. He has remained there forever, a warning to all, as the strange conical outcrop with what looks like a headdress. The story makes this desolate area come to life and it is a pity that the place — like so many other important sites - should remain nameless.

In those areas where Aborigines suffered most dispossession, the transmission of the Indigenous placename network has been broken, and sometimes the only record of that network is in the overlap with European placenames. This is the case in most of the capital cities. Thus in Adelaide, the last person who spoke Kaurna as a first language died early in the twentieth century, and old Indigenous placenames survive only in placenames adopted by the Europeans, such as Patawalonga, a creek, and in those names recorded in the nineteenth century but not adopted as official placenames. Documenting placenames in such areas of 
long-established dispossession requires historical and philological reconstruction, based on archival study as well as geographical interpretation, as Amery's paper shows. For the reconstruction of a vanished Indigenous placename network it is also essential to have good documentation of existing, relatively intact, Indigenous placename networks in similar environments, so that, with due consideration of the diversity of Indigenous toponymic practices, extrapolation of naming principles can be made. Ryan's paper shows how important such cultural considerations are in reconstructing the meanings and significance of placenames.

As the introduced placename system is gradually superimposed on the Indigenous placename networks, there are transitional periods, often resulting in loss of names for features, as Harvey (1999) shows. In the Bardi dictionary (Aklif 1999) Gedda Aklif included well over 300 Bardi placenames. She has explained (Aklif pers. comm. 2000) that she did so at the request of an old Bardi man who was worried that younger people were losing the placenames, and that this hampered their ability to describe where they had been. They sometimes could not name the reefs where they had been fishing.

During the superimposition, Europeans sometimes incorporate Indigenous placenames into the introduced system, and the reverse also happens: Indigenous people incorporate introduced placenames into the Indigenous networks, as Donaldson's and Sutton's papers discuss. So, last century Kaurna people used placenames like Adelaide, while Europeans took over Yurre idla from Kaurna for Uraidla in the Adelaide Hills. But there is one difference in the early incorporations. The Indigenous people by and large took over the European placenames for places in their area, and used them with much the same reference as the Europeans used them. These places may have already existed and had names, such as hills and creeks. Or the names may have been names of newly created settlements or habitation structures. Thus Wilkins (this volume) notes Arrernte people calling town camps by the names of adjacent structures, e.g. Trucking Yards camp.

But the Europeans often took over the Indigenous placenames without much consciousness of their meanings or referents, as Ryan's and Monaghan's papers show. In South Australia, Uraidla (discussed in Amery's and Amery and Williams' papers) is a good example. It means 'two ears' and was used by the Kaurna people to refer to 'Mount Lofty and the adjoining point' (Teichelmann and Schürmann 1840). However, the Europeans used it as the name of a town nearby. Europeans were not always conscious of whether the name was a placename, and also assigned Indigenous placenames from one area to another place, as McConvell's and Ryan's papers show. This could be to commemorate a place, which is not uncommon with house and farm names. Or it could be via another commemoration; apparently the place Tarcoola in South Australia is named after a horse that won the Melbourne Cup. They also used words from Indigenous languages as placenames. For example, in the 1930s the goldfields near Tennant Creek were named the Warramunga goldfields after the Warumungu, the traditional owners of the country, a practice known in English toponymy (Cameron 1996). This name was then taken up in the 1960s as the name of a Tennant Creek discussion club, the Warramunga Club, ${ }^{3}$ which then led to references to the 'Warramunga ladies', none of whom were Warumungu women.

The extreme end of such incorporation is found in newly coined names, whose form is intended to evoke the sounds of Indigenous languages. A nineteenth century example: the Adelaide suburb Glenunga which consists of the Scots 'glen', and the Kaurna locative ending nga. More recent examples: a house called Didjabringabeeralong and another called

The club appears to have been disbanded in about 1981, just before land claims made residents of Tennant Creek more aware of the Warumungu as traditional owners of the country. Files relating to the Warrumunga Club are held in TF140, archives of the Tennant Creek branch of the National Trust. 
Yankaponga part way between the towns of Yankalilla and Myponga ${ }^{4}$ (and Amery provides further examples). The lack of respect for Indigenous naming practices led to the naming in 1956 of a new Aboriginal community on Alyawarr/Kaytetye country, Warrabri, an invented name combining the names of two groups who had been moved there: Warumungu (then spelled Warramunga), Warlpiri (then spelled Walbiri), with perhaps the echo of New South Wales placenames like Narrabri and Boggabri. ${ }^{5}$

As time goes by, Indigenous Australians modify their strategies for naming places as Merlan (2001) indicates. They may adopt introduced placename strategies. Thus the Nakkondi/Look exhibition of photographs of Indigenous Australians (held at the State Library of South Australia, April 2000) contained a photo of two men standing in a garden in front of some roses. The caption was:

Timothy and Ian, Yankalilla 1999. This is my land. I call the place Narangana, Narungga of my mother, and Kaurna this land of my father.

The name is unusual both because it is a blend and because it is a commemorative name, neither of which are common strategies in Indigenous Australian placenames. A different example: an Aboriginal outstation near a Miyilpurnuru 'crow' site in Tennant Creek has been called Crow Downs (Ruby Frank pers. comm. to Jane Simpson, 28 May 2000). Downs is a topographic descriptor which links the outstation explicitly to local stations such as Brunette Downs and Rockhampton Downs. But Warumungu placenames in general do not have topographic descriptors as their second element. Again, documentation of these kinds of changes that take place in Indigenous placename networks under the influence of the introduced network will be crucial for interpreting old records when reconstructing vanished Indigenous networks. The difficulties of interpreting placenames once transmission has been broken or severely diminished are shown in Amery's, Hercus's, Ryan's and Schebeck's papers.

Tunbridge not only stressed the importance of documenting the Indigenous placename network. She also emphasised the importance of assigning Indigenous placenames to otherwise unnamed features. Attempts to incorporate Indigenous placenames officially occurred as early as 1840 in South Australia, when Governor Gawler expressed 'the wish ... to keep to the native names of localities' (see Amery and Williams, this volume), and recurred at the 1884 International Provincial Geographical Conference in Melbourne which advocated using Indigenous placenames as official policy (Henderson \& Nash 1997). Tunbridge also advocated reinstating Indigenous placenames. This practice had happened as early as 1840 when, at Governor Gawler's request, the name Field's River for a river south of Adelaide was changed to what a settler, revealingly, described as 'its proper name of Onkaparinga' (Hawker $1975: 41){ }^{6}$

\footnotetext{
Simpson saw the first in 2000 in Mittagong, New South Wales, and the second in 1999.

5 The name has since been changed to Ali Curung, an attempt to render the Alyawarr Alekarenge 'dog-associated', a reference to the Dog Dreaming of the country.

6 Whether 'Onkaparinga' was the proper name for the whole river is doubtful. Support comes from Teichelmann and Schürmann (1840) who give Ngangkiparringga as the whole river Onkaparinga. Teichelmann (1857) refers to the River $N g a n g k i$, as well as Ngangkiparri 'the lady river'. However, Meyer (1843) gives three names, including Ngangkiparingga, for 'Horse-Shoe' (probably the bend in the river close to the sea).
} 


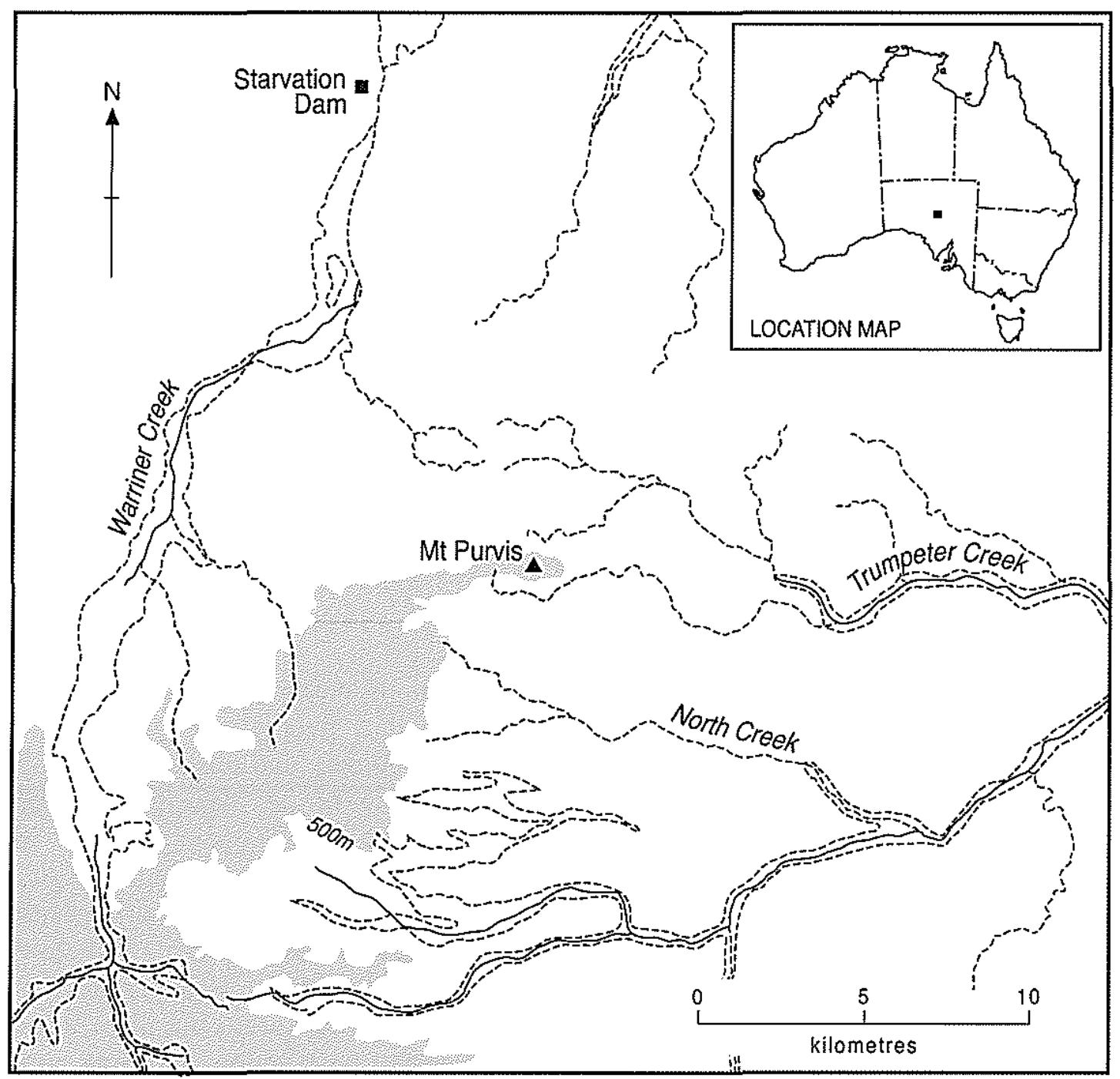

Map 1: Mount Purvis and surrounding area 


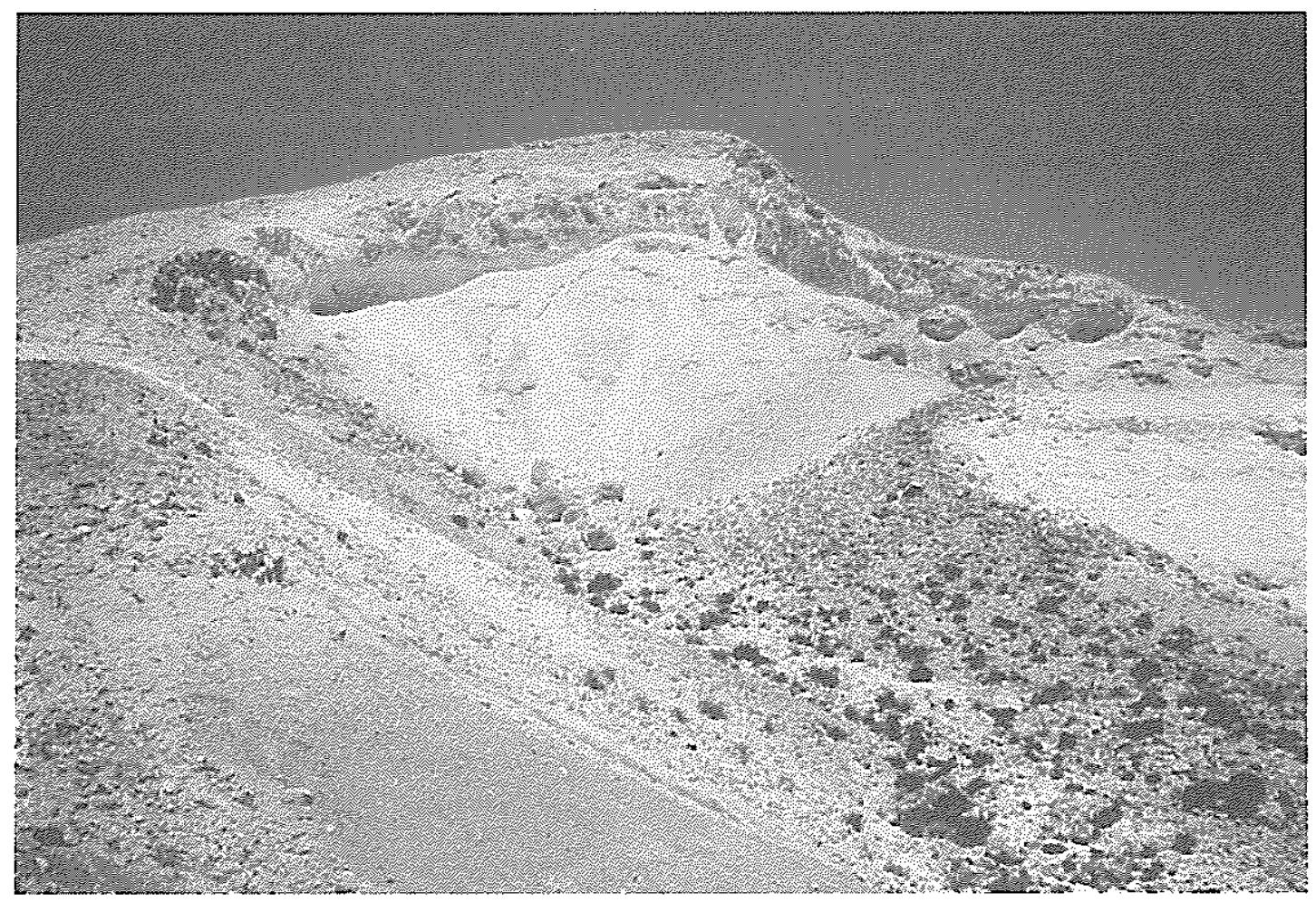

Figure 2: Mount Purvis 'the Old Woman Busted’ Photo: C. Macdonald

Like Gawler, others have wanted to restore Indigenous names, sometimes noting the discourtesy of imposing introduced names when Indigenous people are still using a rich system of names for places (Tunbridge 1987; Sutton, this volume), and sometimes arguing for the desirability of enlivening the landscape by introducing further Aboriginal names on ordinary maps. For example, Ulyurla Palthiyangunga 'the Old Woman Busted', Mount Purvis, is a well-marked place on the Billa Kalina map sheet in what was traditional Arabana country (53J 0588100E 6742900N, Billa Kalina SH53-7). The main site is a huge erosion gully on the northern face of the east-west ridge that makes up Mount Purvis. The gully has cut back to the top of the ridge about 300 metres west of the trig. In its upper reaches it is about 150 metres wide with near-vertical slopes, but it discharges onto the plain through a narrow channel with a gentle slope. The rocks exposed are pale yellow and pink and they contrast with the darker brown of the surrounds. In a myth and song cycle, again now mostly forgotten, the Ancestor Thunpila carries the decaying body of his dead wife in order to bury her, and at this place the body more or less explodes and 'all her innards fall out'. A letter from 'Moodloowardoo' to the Adelaide Register laments of this place and its name that:

Yet all this interesting if primitive piece of geological tradition, with its excellent moral inculcating abstemiousness, is lost under a small triangle with a dot in the centre, branded on our plans Mount Purvis, in memory no doubt of some estimable but probably prosaic gentleman. (cited in Cleland 1952 from Cockburn 1908:66)

In remote areas, such as the Pitjantjatjara lands in northern South Australia, assignment and reinstatement of Indigenous placenames are relatively uncontroversial. In areas that have been settled by Europeans for long periods, assignment of Indigenous placenames may have sentimental cachet and even market value. Thus, new vineyards in southern South Australia 
and Victoria sometimes have names from Aboriginal languages, although the languages have not been spoken as first languages since early in the twentieth century. One might speculate that using a name from an Aboriginal language to name one's property gives the illusion of a long-term relation with a place, an unbroken chain right back to the original owners, and perhaps also the illusion of a connection with a lost age of simple living (which would link with ideas of the virtues of 'traditional' wine-making). Reid's paper in this volume discusses some of the linguistics issues involved in assigning new names.

In such areas, while assignment of names to features without names may be easy, reinstatement of names can be controversial, as the attempt to restore names in and around the Grampians National Park showed (Clark and Harridine 1990). However, rather than replacement of introduced names, dual naming policies are gradually being adopted. For instance, as Amery and William's paper discusses, Kaurna people have been working towards dual naming for some parts of the City of Adelaide, in conjunction with the City Council and the South Australian Geographic Names Board.

But in areas where both Europeans and Aborigines live, Indigenous placenames are often ignored. Thus in 1999 the town of Tennant Creek in the Northern Territory had about 50 per cent Aboriginal population. No streets or parks or public spaces were named after Aborigines, or had names in the local language, Warumungu. Only organisations primarily relating to Aborigines and town camps had Warumungu names. As for Alice Springs, Petrick (1996) lists about 550 placenames (mostly street names). About 30 have their origin in an Aboriginal language, and the majority of these are not original Arrernte placenames, but rather Arrernte words for flora and fauna applied to streets.

Since Tunbridge's paper, the State and Territory nomenclature authorities have been working towards policies on assignment, reinstatement and dual naming, in consultation with Indigenous communities. Their draft policies are given in this volume. William Watt of the South Australian Geographic Names Board has worked with Tunbridge and Adnyamathanha people to assign Adnyamathanha names to various features in the Flinders Ranges, and with Pitjantjatjara people and the linguist Cliff Goddard to assign names in the Anangu Pitjantjatjara lands in the north-west of South Australia. They have also been able to work with Ngarrindjeri people and older records to assign Indigenous names to features without existing official names along the Coorong. A further official step has been the use of the recognition of Indigenous placenames as an indicator for the state of Aboriginal languages, as part of national state of the environment reports (Henderson \& Nash 1997).

Reinstating Indigenous placenames is seen as a mark of respect for the Indigenous peoples of Australia. In some areas, however, too few of the Indigenous placenames survive for this to be possible, as Reid notes for Armidale. In such cases people have attempted to remedy this by using words from the Indigenous languages as placenames, sometimes commemoratively, as in Amery's proposal to name places in Adelaide after prominent Kaurna people, and sometimes by taking words that sound good to both Europeans and local Aborigines, as Reid discusses for new official names in Armidale City taken from the Anewan language. Reid's paper also addresses the difficulties of pronunciation involved in incorporating words from Indigenous languages into the introduced placename set.

Reinstatement and assignment of names (placenames or otherwise) from Indigenous languages raise difficult and sensitive issues. Essentially the issue is this: if Indigenous names are brought into the official introduced placename system, they are in the public domain. This provides public recognition of the names, and thus of prior occupation of the country by Aborigines and Torres Strait Islanders. But once the names are in the public domain as 
placenames, then, as Reid puts it, they become a commodity. They can be used, say, in business names, without permission being granted by the Indigenous owners of the placenames. Some Kaurna people, for example, dislike the idea that a Kaurna placename, such as Karrawirraparri, could then be used in a business name, say the Karrawirraparri Greeting Card Company, and perhaps create favourable feelings among potential clients, without Kaurna people being consulted. Williams raises this issue in the Amery and Williams paper.

The intellectual property involved in using words or placenames from Indigenous languages is illustrated in a dispute, unresolved at the time of writing, about a new vineyard called Koppamurra in the south-east of South Australia (Altman 2000). There has been a telephone exchange and a station in the area called Koppamurra since the early twentieth century, and it has been recorded on maps since the 1940s. The form of the name suggests that it is probably derived from an Indigenous language. But the vineyard owners wanted to trademark Koppamurra and argued that 'any geographic use of the name would be deceptive and confusing and place its trademark at risk'. The fact that the word is likely to be a word of an Aboriginal language did not prevent the vineyard from being able to trademark it.

So, sensitive consultation is needed with communities before any Indigenous placenames are taken over into the introduced placename network. While Indigenous placenames can be reinstated to some extent, Indigenous placename networks are a different matter. Reinstating an Indigenous placename network amounts to reinstating a way of looking at the land, together with a set of associated responsibilities, and would probably only be possible on areas of land such as the Anangu Pitjantjatjara lands which Aborigines hold title to.

In the rest of the paper, we want first to outline briefly, important differences between the introduced placename system, and the set of Indigenous placename networks; and second to discuss strategies for forming placenames used in a number of Australian Indigenous languages.

First we discuss four differences between Indigenous and introduced placename systems. Then we mention three strategies for creating introduced placenames which are rarely found in Australian Indigenous placenames. Finally, we discuss the meaning and interpretation of analysable Indigenous placenames, focusing on southern and central Australia.

\section{FOUR DIFFERENCES BETWEEN INDIGENOUS AND INTRODUCED PLACENAMES}

The two systems of placenames differ in a number of ways, for example, whether the placenames form networks, how they act as mnemonics, what uses are made of the land, and what counts as a significant feature.

\subsection{System versus set of networks}

First, before 1788, Australia had no centralised government and no means of coordinating a single set of placenames. Each group had its network of placenames which linked in with its neighbours' networks, most noticeably at the boundary areas, but not only there. The result was that one place might have several names. It is also the case that different groups will have different strategies for forming placenames.

After 1788, a single official set of introduced placenames was codified. The idea was that this set of placenames would be known to and used by everyone who needed to use them. Of 
course, in particular areas settlers developed their own networks of unofficial introduced placenames - names for paddocks, dams and bores on farms, for example. But, in general, the single official network of introduced placenames contrasts with the many local networks of Indigenous placenames. There is also contrast in ownership. The official set of introduced names is not owned. Everyone who wants to can have access to it, through maps, gazetteers and the like. But the Indigenous placename networks are very often owned. One family may have the exclusive right to impart information about particular places, including their names. Some placenames may be powerful and may be secret or sacred, not for public distribution, as is clearly demonstrated in Tamisari's paper.

\subsection{Local mnemonics versus mnemotechnics}

Second, all placenames are shorthand labels given to significant geographic features for the purposes of finding them again, referring to them, and passing on the knowledge of the place to other people.

In the past, in areas where people have lived for a long time, without major disruption, placenames have developed organically as local mnemonics to refer to places. Thus, for example, the English placename Taplow comes from 'Taeppa's burial-mound' (Cameron 1996). We can easily imagine that soon after the mound was built, people started referring to it as in 'Take a right at Taeppa's burial-mound', and that over time when a settlement grew up in the area, people could become quite unaware that the name even referred to a burial mound rather than to the settlement.

While the organic development of placenames as local mnemonics in England is partly comparable to the Indigenous placenames networks of Australia, the English local mnemonics do not form a coherent mnemonic system in the way that Indigenous Australian placenames in many areas do. The invention of writing and of mapping meant that English placenames could be stored for long periods and sent long distances. The name Taplow would start to be used by people who had never been to the area, and never seen the burial mound. Writing and mapping reduced the need to have names that were memorable as having meanings that related directly to a particular place. The relation between the sense of the name and the referent of the name could be quite arbitrary. Instead, names could be used for other purposes, say, to commemorate a person, Adelaide, or to commemorate a much-loved place, $\mathrm{New}$ England.

In this respect the Indigenous placename sets of England differ from the Indigenous placenames networks of Australia. Indigenous Australians by and large did not have long-term placename storage devices like paper maps, with the possible exception of the Diyari toas mentioned in Jones's paper in this volume. But they had huge numbers of placenames to remember. Peter Sutton (pers. comm.) calculates that some Wik people on Cape York know several thousand placenames.

The effort of remembering not only the names, but also where the places are that they name, seems enormous to us. We are used to refreshing our memories from written material. People without such aids develop mnemotechnics, systematic mnemonic systems. In such systems, the mnemonic value of the name is important, but it must also be easily memorable as part of a system, as for example in the mnemotechnics of classical and mediaeval Europe (Yates 1969), a sequence of things to be memorised was associated with something else which had an easily graspable order (the seating plan at a feast, a room, the floorplan of a palace, a theatre). 
Many groups in central and southern Australia devised similar but more elaborate mnemotechnics discussed in Strehlow (1971). To remember where a place is, and what it is like, the placename is associated with the travels of Ancestral Beings. Warumungu ancestral women go to the place Wiitin and leave a coolamon. That is visible now as a waterhole. Wiitin means 'coolamon' in Warumungu. They go east to another place, Manaji, where they dig bush potatoes. Manaji means 'bush potato' in Warumungu. Tamisari's paper contains several excellent examples of the association of topographic features with evocative ancestral activity - yellow ochre as ancestral faeces, for example. These travels and actions are represented in story, song, sand drawings, body painting and dance, and, as Wilkins (this volume) points out, the placenames are an essential part of the stories. In fact, a placename can then act as a reverse mnemonic - while it acts as an aide-memoire for locating a place, it can also act as an aide-memoire for events happening at that place, for the story (Basso 1996). That is, such placenames have a non-arbitrary relation to the place, as Merlan (2001) elaborates on for Jawoyn placenames. Moreover, as Merlan also points out, if a placename concerns actions of Ancestral Beings, those actions may also be carried on by humans at that place. Thus, circumcision was carried out at a Jawoyn place whose name invokes the story of an Ancestral Being carrying out circumcision at that place.

The sequencing of placenames according to the travels of an Ancestral Being is undoubtedly important for remembering a sequence of placenames, and thus the location of those places. In this sense Indigenous placenames can be described as a network. They are linked by more than the fact that they are names given to places (Wilkins, this volume). By knowing the story one knows something about the place, and about its location vis-à-vis other places. Places are connected by the story.

However, the dreaming track mnemonic is only one strategy used. Not all places are well connected in the network; some places may just stand on their own. They may have a story that is not linked to other places. And in fact not all areas of Indigenous Australia use the long sequences of names associated with travels as the main mnemonic technique, as Sutton (this volume) notes. Moreover, not all names are easily analysable (Walsh, this volume). The names mentioned above are clearly analysable, and are obviously easy to interpret as mnemonics. But, in fact, different Indigenous placename networks vary dramatically as to how interpretable the names are. For example, Luise Hercus has found most of the Arabana placenames are interpretable. But Sutton (this volume) observes that in the Wik region more than 50 per cent may be unanalysable. There are many reasons for this: the linguist's lack of knowledge, the loss of the language, or, as Sutton describes, the people may have switched to using another language but have kept the placenames in the earlier language. Another reason may be that places have several names. Some names may be esoteric, so that only a few people know the connection between the meaning of the name and the place that it refers to. Walsh's paper discusses the consequences of this.

Instead, other methods for preserving and transmitting the knowledge of places are used. Nash (in prep.) has observed the importance of toponymic gossip, talking about places, retelling stories of trips, as ways of keeping memory of places alive. Sutton (pers. comm.) notes the importance of competitive placename calling; he describes men competing with each other in naming places. Related to this is Aklif's (pers. comm.) observation that her Bardi teacher indicated that a person who can name a place has a special connection to that place and when a person cannot name a place anymore that connection weakens. 


\subsection{Uses made of the Iand}

A third important difference between Indigenous placename networks and introduced placename systems has to do with the different uses made of the land. Australian Aborigines for the most part did not build permanent structures, such as houses, bridges and roads. This has a number of consequences for placenames. It emphasises the importance of systematic mnemonics. One can find out the name of the place Taplow by asking the people who live there, 'What do you call this place'? But in the unusual situation when hunter-gatherers are travelling and come to a waterhole whose name they do not know, they cannot expect to find someone living there who will tell them the name of the place. Rather, they will have to rely on being able to describe the place later to someone who might know it, and learning from them the name of the place.

The lack of permanent structures also has consequences for placenames. English placenames have been classified by Cameron (1996) into two main types: 'habitative', 'topographical' and a third, lesser type 'names of tribes'. The 'habitative' placenames reveal the changing habitation patterns of sedentary lifestyle, as well as the change of dominant languages - the -cester of Roman camps, the -by and -ton of towns, and the bridges, the markets, the mines, the fields.

\begin{tabular}{ll}
\hline INDIGENOUS & INTRODUCED \\
\hline Kaurna: wodli 'house, hut' & Fairfield \\
Warkowodliwodli Klemzig (Warko?) & Civic Centre \\
Tambawodli Emigration Square (tamba & and many indigenous to the UK, e.g. names \\
'plain') & ending in -ham, -by, -thorp, -ton, \\
Piltawodli the Native Location (pilta & -cester. \\
?possum) (Amery and Williams, this volume) & \\
\hline
\end{tabular}

By contrast, Indigenous placenames in central and southern Australia have far fewer habitation structures to record. In fact, it is exceedingly difficult to find Indigenous placenames that make explicit reference to habitation. That is, we do not find names of the form 'X Camp'. Some Indigenous placename networks, however, do allow placenames to combine with generic uses of words meaning 'camp/place' such as the Arrernte use of pmere 'camp, country, place' discussed by Wilkins (this volume). Probably related to the lack of placenames involving habitation structures is the lack of placenames for paths or trails, other than the idea that a route is that taken by an Ancestral Being.

However, people clearly do live in the country, camp at places, and occupy them. McConvell's paper raises the intriguing question as to whether the extension of names of sites to areas has to do with the way people use the area.

\subsection{What counts as a significant feature}

A fourth important difference between Indigenous and introduced placename systems is what counts as a significant feature to be named. As we said earlier, placenames are labels given to significant features for the purpose of referring to them in discussion with others. What count as significant features depends on what impression the feature makes on a person seeing it, or in the case of some water features, on the person hearing it. Thus we might expect a large red mountain rising out of a plain to have a name. And we might expect water features to have names, as Donaldson (this volume) shows for the Ngiyampaa. 
But we should not expect a one-to-one match between the kinds of topographic features usually given names in the Indigenous British placename set, and those given names in Indigenous Australian placename networks. Thus, in the Warumungu land claim, it emerged that a prominent hill called by the Europeans 'White Hill' was called by the name of the surrounding area, Parakujjurr 'cut-two', which includes two rockholes, the specific referents of the placename. Similar differences in the extent of the area referred to by Indigenous and introduced placenames are discussed by McConvell for the Gurindji. Another difference is in the naming of creeks. As Tunbridge (1987) noted, the Adnyamathanha name parts of creeks, not the whole creek. ${ }^{7}$ This is true in many parts of Central Australia as well. However, as Peter Sutton (pers. comm.) notes, in the Wik area of Cape York, generic terms for words like 'creek' are prefixed to names, and seem to denote the whole creek.

\section{THREE STRATEGIES FOR CREATING INTRODUCED PLACENAMES RARELY FOUND IN AUSTRALIAN INDIGENOUS PLACENAMES}

Both the Indigenous placenames networks of Australia and the Indigenous placename system of England developed slowly. In this respect they are radically different from the introduced placenames network of Australia. The invasion and settlement of Australia took place so rapidly that in many areas there was no time for local mnemonics to develop. The administration of the country required rapid labelling of the country so that people could communicate with each other and be sure they were referring to the same place. Particular people, explorers and surveyors, were given the task of bestowing names on places. They used different strategies for designing the names. Sometimes surveyors were given instructions, which often included trying to find Indigenous names for localities, as Monaghan discusses. But a major strategy used was commemoration.

\subsection{Commemoration strategies}

Explorers who had to pay the bills named places after wealthy sponsors, for example Glen Elder, Joanna Springs. Many introduced placenames commemorate people or places by using the name of the person, such as Adelaide, or of their rank, Kingston, or the name of the place, such as Richmond. Sometimes a qualifier is added, such as 'New' in New South Wales and New England. We have rarely encountered such commemoration strategies in Indigenous placenames networks (McConvell, this volume). We have come across places bearing the personal name of an Ancestral Being (which may happen to be the name of a living person).

An example of a person giving their name to a site within the framework of traditional naming is that of the Tyimama sandhill, on the north side of the Spring Creek floodout in the Witjira National Park in Lower Southern Arrernte country. In the Urumbula myth and song cycle the Cat Ancestor brings handsome young women with him all the way from Port Augusta and picks up more on his journey north. He leaves behind the more elderly ones and they are represented in the landscape by hills or sandhills. One high and crimson sandhill is called Tyimama, and there is a Urumbula verse naming it, probably composed around the turn of the century. Apparently the verse and the site belong to a Dalhousie woman who had taken on the European name of 'Jemima'.

Possibly the European propensity for naming the whole river comes from river transport - travelling and trading up and down rivers probably assist in naming whole rivers rather than just places along the river. 
But much more commonly we have seen the name of a place used as a personal name. This is akin to the way many English surnames are derived from places, and to the way that Australians in farming communities may refer to people by the name of their property. 'I heard Woolcunda on the radio yesterday.' It relates closely to ownership. Knowing the name, the story, the songs and perhaps dances and designs associated with a place is an important part of owning the place; displaying that knowledge can be a way of 'performing' one's ownership of that place. One kind of display of ownership is by bearing the name of the place. For example, Ronald Berndt's Yaraldi teacher, Albert Karloan, had a name Djinbatinyeri, derived from the place Djinbatung (Berndt et al. 1993:148). ${ }^{8}$ Among the Warumungu, Simpson has heard people addressing the senior owner of the Snake and Star Dreaming using the name Jajinyarra, an important place on the dreaming track. This intimate relationship between personal names and placenames is elaborated on in Tamisari's paper describing the Yolngu practices in Arnhem Land.

\subsection{Topographic descriptors}

Second, many Indigenous placenames of the United Kingdom include topographic descriptors, as Baker's paper points out. They illustrate a classification of the landscape, and are found in British placenames from Celtic times onwards: Strathspey, valley of the Spey river, Strathclyde, valley of the Clyde river, Inverness, mouth of the Ness river, Inveresk, mouth of the Esk river. Many introduced placenames also include topographic descriptors: Mount Remarkable, Lake Eyre, Point Pearce, Coffin Bay, Second Creek, River Murray and so on. Such an explicit classification is helpful for newcomers to an area, who are reading a map and wanting to associate the explorer's names with what they see (but see Carter 1988:110 on the discrepancies between what an English explorer might call a 'lake' and what an English reader might imagine a lake to be).

We have found little trace of such classification in the Indigenous placenames we have looked at in Central and Southern Australia (not one of 689 distinct Warumungu, Warlpiri and Wakaya placenames contain a clear topographic descriptor). Donaldson (this volume) makes a similar observation for the Ngiyampaa of New South Wales, and Baker (this volume) shows that this is also true in the middle and lower Roper River area of the Top End of the Northern Territory. Arrernte (Wilkins, this volume; Harold Koch pers. comm. 1999) has a few names involving topographic descriptors such as 'pwerte 'hill' and, rarely, X kwatye 'water'. However, absence of compound names including topographic descriptors is not true of all Indigenous placename networks. There are some notable exceptions:

(i) In areas where generic classifiers are used, such as the Wik languages of Cape York, Peter Sutton (this volume) has noted the use of generic classifiers like 'creek' prefixed to a name, and given as the name of a creek.

(ii) In a number of networks in South Australia, there are compound placenames using the word for 'water', kawi, kapi often reduced to -awi (Hercus and Potezny 1999), and in Kaurna, the word parri or pari 'river', ${ }^{9}$ as in Warriparri, 'Sturt Creek' discussed by

\footnotetext{
It was formed by dropping the ending -ung (probably a locative ending) and adding the 'belonging to' morpheme -inyeri.

9 The spelling used for Kaurna is that of Teichelmann and Schürmann (1840). In fact, parri almost certainly had a retroflex continuant.
} 
Amery. However, the parri forms are not entirely convincing, because, while the Europeans applied them to the whole of the river, wanting as they did a name for the whole of the river, we do not know if this is what the Adelaide Plains people did.

(iii) Perhaps the most striking exception is provided by Schebeck's paper in this volume. He notes that almost a third of the 483 Flinders Ranges placenames he looked at are compound names including topographic descriptors. While the awi and vari (parri) forms mentioned above predominate, he lists 19 other topographic terms used. John McEntee points out (pers. comm. to Jane Simpson, 10 May 2000) that some, such as Yurntu Vuri 'sun stone/hill', involve older words for 'stone', while others, such as some of the many with vambata 'hill' in their names, may indicate more recent European influence in placename construction.

Environmental classifications are used in placenames. For example, in the networks we have investigated, we do find topographical descriptors, but as the main element, e.g. Wulpayi 'creek' (Warlpiri), Alinjirri 'floodout' (Warumungu). We have also come across placenames referring to ochres or pipeclay resources as the main element: Palanmirrijangu 'white clay-having' (Warumungu), Wapanjara 'red ochre' (Warumungu), Karrku 'red ochre' (Warlpiri), Kartjiparnta 'pipeclay-having' (Warlpiri), and compare Baker's Marra Mayngu 'red ochre'. Hercus's paper discusses problems of whether these are actual placenames or descriptions of the topography, a point taken up in Schebeck's paper.

But the major environmental classification is dominant vegetation. Thus, in the Warumungu land claim, of more than 680 distinct placenames, more than 80 clearly involve names of vegetation. Baker (this volume) notes similar properties in the Roper area, and a considerable number of the Yidiny placenames for which Dixon (1991) gives meanings refer to vegetation.

VEGETATION

$\begin{array}{lll}\text { Kaurna } & \begin{array}{l}\text { Korra weera, yerta } \\ \text { and perre }\end{array} & \begin{array}{l}\text { Adelaide, and the Torrens. From karra } \\ \text { 'red gum', wirra 'forest'. }\end{array} \\ \text { Yaraldi } & \begin{array}{l}\text { Muwantjangali, } \\ \text { Muwandjingal }\end{array} & \begin{array}{l}\text { dense pine forest ?from Nebuluwar to } \\ \text { East Wellington (Berndt et al.1993:14, } \\ \text { 313-314). Compare Ramindjeri mowantye } \\ \text { 'pinewood' (Meyer 1843). }\end{array} \\ \text { Warumungu } & \text { Purrurtu } & \text { 'coolibah' - name of group's country. } \\ \text { Yidiny } & \text { Jalngganji } & \text { jalnggan 'milky pine' + -ji 'with' } \\ \text { (Dixon 1991). }\end{array}$

This emphasis on vegetation probably reflects hunter-gather attitudes towards land too. If land is not being cleared for farming, then the vegetation, ti-tree, pine or grasses are a fairly permanent part of the landscape, suitable for a mnemonic.

A possible interpretation of the lack of topographic classifiers in many Indigenous placename networks is, as Anna Wierzbicka (pers. comm.) suggests, that in these networks placenames have a default head 'place, area, country', just as in the introduced network, the default reading of an introduced name without a topographic descriptor, such as Adelaide, 
probably is 'place of habitation'. Wilkins (this volume) explores in detail the use in Arrernte of a generic pmere with placenames while Alpher (this volume) notes the widespread use of a generic pin 'home-place, country' occurring as a part of Yir-Yoront tract-names (but omissible), and Simpson has noted in Warumungu narratives the use of manu 'country' appearing as a separate generic word together with placenames.

\subsection{Relative location}

A third difference is that neither Indigenous placenames in Britain nor introduced placenames in Australia show the kinds of systematic mnemonics described above for Indigenous Australian placenames, which allow the creation of large networks of placenames. However, they do sometimes form smaller networks through the use of indicators of relative location. As English speakers we are used to placenames that have as part of the name a cardinal point, North Adelaide, and so on. Usually they refer to a settlement that is east or south of some other settlement, often larger. It makes sense to name a smaller settlement or structure by reference to a larger landmark, or else naming a part by reference to the whole: South Australia, East Gippsland. Cardinal points are classic markers of relative location, but there are also markers of relative altitude or upstream, like Upper Sturt, Lower Mitcham, Naas and Top Naas in the Australian Capital Territory, Top and Bottom Baldknob Creek, Bottom Pigstye Swamp, Top Camp; relative distance to a place, Outer Harbor, relation to some named place, Noarlunga and Old Noarlunga in South Australia, Hartley and Little Hartley, and Back Yamma Forest in New South Wales.

But we have not come across this system of explicitly marking relative location ${ }^{10}$ in the relatively intact Indigenous placename networks in areas where we have worked in Central and southern Australia. This may be a result of the fact that people travelled much of the time, and of the lack of names for settlements or camps. Settlements are obvious reference points for relative location markers to develop from. Of course, in principle there is not any reason why people did not develop names for regular campsites that locate topographic features with respect to other topographic features - why not have 'east of the mountain', 'south of the river' as placenames?

However, the fact that the relatively intact Indigenous placename networks in some areas do not seem to use cardinal points means that we should be at least suspicious of placenames from Aboriginal languages that contain cardinal points. For example, in the nineteenth century the word Cowandilla was recorded as the name of a place in Adelaide. However, early sources have:
Kobandilla
Districts of the Adelaide tribe
Wyatt (1879)
kawandilla
'in the north'
Teichelmann (1857)

Where did this name come from? Is this name likely to be used by the traditional owners of Cowandilla to represent their country? Why would they call their countries 'in the north' respectively? North of what? We do not know the circumstances of the bestowal of these two names. Which Aborigines gave the Europeans these names? What did they think the

10 There is in Central Australia a partial system of relative location in that places which have the same name are sometimes said to be linked. But it is nowhere near as extensive as the system in the United Kingdom. 
Europeans were asking? What did the Europeans think the names referred to? But we do know that two important cultural brokers, Mullawirraburka and Parnatatya, who worked with the missionaries and protectors recording the language of the Adelaide Plains were men whose country was south of Adelaide. Thus, from their perspective Cowandilla would be in the north. If they were asked the name of the Cowandilla area, they might well have said, 'It's in the north'. However, see Amery (this volume) for an account of another Kaurna name involving a cardinal point: Patparno, Patpungga Rapid Bay (Wyatt 1879) 'in the south', for which we do know one instance of the use of this name when it cannot have meant 'south of where we are talking'.

This lack of relative location indicators does not hold in certain other areas, such as the Wik people of Cape York, as Sutton describes. Hence, the cardinal points in the Adelaide Plains name could be genuine names. We simply do not know enough about the toponymy practices of the Kaurna to judge.

\section{SEMANTIC CONTENT OF INDIGENOUS PLACENAMES IN SOUTHERN AND CENTRAL AUSTRALIA}

The meanings and interpretations of Indigenous Australian placenames are the subject of most of the papers in this volume; however, several focus on general problems of interpreting placenames. Thus Schebeck discusses what is a placename, as opposed to a description or a secondary name alluding to some aspect of the story. This relates to the problem of distinguishing between what is a proper name and what a common noun. In some languages, such as Yankunytjatjara (Goddard 1985), or Ngalakgan, Alawa and Marra (Baker, this volume), the distinction is made in the morphology; special allomorphs of case endings appear on proper names. But in others, placenames are harder to distinguish from common nouns. However, distinctive endings, such as the comitative and locative suffixes that are often found on placenames, serve a different purpose, marking out a name as belonging to a particular language. Thus Kaurna has many placenames ending in the locative -nga or -(i)lla, while its neighbour Ramindjeri has placenames ending with a locative -ng: Ramong and Wirramulla both refer to Encounter Bay and have the same root. Genitives can have the same function: the Warlpiri place Yankirri-kirlangu 'emu-belonging' is translated closely in Warumungu as Karnanganja-kari. Indeed, if names are interpretable and are transparent mnemonics, then they are likely to be translated by neighbouring languages. Thus the same feature may have two different names, both with the same sense, but with different forms. An example from Hercus's fieldwork: 'the Fire-track', i.e. the Macumba River, Makampa/ URingka (from maka-wimpa in Arabana, uRa-ingka in Arrernte). This translatability reduces the ability to track movements of people and languages over time through placenames, as Harvey (1999) shows for the Top End, and as Sutton notes in his paper. But, as Walsh's paper points out, Indigenous placename networks vary as to their analysability. Merlan (2001) says that a considerable number of Jawoyn places had associated stories but they had names that were hard to relate to the story. Alpher's and Baker's papers show that in some areas there is plenty of evidence for archaisms being retained in placenames. Likewise Sutton discusses ancient placenames in Cape York whose forms conflict with the phonological structure of the currently dominant local languages. He considers the question of whether stable land-language relations are likely to lead to more or less analysable placenames. 
Here we summarise our experience in interpreting central and southern Australian Aboriginal placenames. We divide them roughly into four types (excluding those that linguists have been unable to analyse), along a continuum.

Semantic Content of Analysable Indigenous Placenames in Southern and Central Australia

\begin{tabular}{|c|c|c|c|}
\hline $\begin{array}{l}\text { descriptions of ---.-> } \\
\text { topography and } \\
\text { environment }\end{array}$ & $\begin{array}{l}\text { description refers to } \\
\text { Ancestral Beings } \\
\text { and environment } \\
\text { simultaneously } \\
\text { literally }\end{array}$ & $\begin{array}{l}-->> \\
\text { figuratively }\end{array}$ & $\begin{array}{l}\text { reference to } \\
\text { Ancestral Beings }\end{array}$ \\
\hline $\begin{array}{l}\text { Parnttarr-kujjurr } \\
\text { 'two cracks' } \\
\text { Karlukarlu } \\
\text { 'boulders' } \\
\text { Purnungkurr } \\
\text { 'swamp' }\end{array}$ & $\begin{array}{l}\text { Kijjiparraji 'white } \\
\text { ghostgum' (the } \\
\text { Mungamunga women } \\
\text { turn into ghost gums) }\end{array}$ & $\begin{array}{l}\text { Para-kujjurr 'two } \\
\text { body-entrances' = } \\
\text { two rock holes } \\
\text { Wiitin 'dish' = } \\
\text { depression in creek }\end{array}$ & $\begin{array}{l}\text { Karnkka 'moon' } \\
\text { Kartti kujjurr 'two } \\
\text { men' } \\
\text { Maliki-kirlangu } \\
\text { 'dog belonging' } \\
\text { Ngurru pakinyi } \\
\text { 'nose pierced' }\end{array}$ \\
\hline
\end{tabular}

(these are Warumungu placenames)

In the first column are names that transparently describe the topography and environment, discussed in this paper, and most strikingly in Schebeck's paper. In the centre, these often occur with suffixes meaning 'having', 'associated with', 'belonging'; thus Warlpiri Ngalyipi-parnta, 'having ngalyipi (snakevine)'. Ash's paper discusses the use of the comitative -baraay in Gamilaraay, and Donaldson does the same for Ngiyampaa -puwan. Sometimes these are no longer productive in the modern language; thus Warumungu has a suffix -riji or -yiji found in a few words lirrppiriji 'claw-having = goanna', and in a number of placenames, Manajiriji 'bush.potato-riji'. (It is, of course, possible that these names designate environment and mythology simultaneously. The bush potatoes are there because ancestral women planted them.)

On the right are names that appear to refer only to aspects of events on an Ancestral Being's journeying, such as throwing a boomerang, urinating, making fire, standing up a spear-thrower and so on. Names such as the Warumungu Ngurru pakinyi '(someone) pierced a nose' belong here. Tamisari's paper discusses these. Merlan (2001) provides interesting Jawoyn examples in which the placename is an ideophone for an action of the Ancestral Being, as the place Gurngurnbam where gurngurn denotes the thudding of a kangaroo. In between are names which refer simultaneously to the story and to the landscape. This may be literally (as in a place named by a tree which the Ancestral Beings did something with) or figuratively, such as Warumungu Jalkaji for a spearthrower which represents a tall upright rock. These names sometimes have variant forms, thus Warumungu Ngurrujarrpijara 'nose-enterer', and Ngurruparramanyi 'nose-sat.down' refer to the same place. Both are allusions to an action happening at the place that is the source of the placename. Baker's paper gives further examples.

Probably most names fall into the middle two kinds. That is, if a name appears to be purely topographical or environmental, it may be that we have lost the associated story. And if a name appears to be purely mythological, it may be shorthand for what an ancestor did at that place. Thus, indirectly, names such as Ngurru pakinyi 'nose pierced' also refer to features of the landscape, but the metaphor is not as transparent as it is with Jalkaji. 
Different placename networks have different hierarchies of places, (McConvell, this volume). Some include both named large areas, 'countries' or 'tracts' (see Alpher's paper for this term), and named sites within those countries, as Baker discusses, while others do not. Most of our observations cover names for sites, rather than names for countries. But we note that Warumungu countries include names whose senses are at both ends of the continuum, Purrurtu 'coolibah', the name for the country belonging to the holders of Jalajirrppa 'white cockatoo' dreaming, and Warupunju, an Arandic word for 'fire', the name for the country belonging to the holders of Warlukun 'fire' dreaming.

A final point on form. Placenames evoking a story associated with a place are sometimes expressed as a verb or phrase, or, as Wilkins (this volume) observes, as a headless relative clause, and examples are provided in many papers in this volume, as well as in Merlan (2001). This is an unusual feature of Australian Indigenous placenames compared with introduced placenames (although it is found in other Indigenous placename systems, e.g. Kari's (1989) discussion of Alaskan Athabaskan placenames). Languages vary as to what percentage of names are expressed this way; Schebeck (this volume) notes that only 14 of the 483 Adnyamathanha placenames he examined were of this form. However, in the Roper area Baker notes that there are a large number of such placenames.

In Arabana some of these are simply verb forms, often marked for the past tense; sometimes the verbs are preceded by a noun subject or object:

Pakalta

Ngampayiwalhuku

Kudna-tyura-apukanha

Thidna-pakanha

Wati-warakanha

RELATIVE CLAUSE

Wabma tharkarnayangu

Yunga kurdalayangu

Pilparu palthiyangunha

Tyalpiyangunha 'he is digging for somebody else', Mount Arthur, Arabana (Present benefactive)

'(they) came to get a grinding stone'

'they (the ancestral Emus) had diarrhoea long ago', Rockwater Hill in Arabana country, where there are lots of green stones

'digging with his foot', the Tidnabucca waterhole on the Macumba, also another site near Coward Springs

'he blocked the track', hill near Anna Creek in Arabana country, the reference is to the Ancestral Turkey who tried to 'perish' the Initiands

'(where) the Snakes stood up', Wommaturkaenamana Bore, in Arabana country

'(where) his waterbag fell down', reference to an Ancestor who got such a fright that he dropped the waterbag he had just filled; alternative name for Burraburrina Well

'(where it, i.e. the whole camp) was split by Lightning', Blanket Waterhole near Belt Bay, Lake Eyre

'(where they, the Initiands whom the Turkey was trying to perish) cooled down', Coolibah Yard near the Lower Neales, close to Lake Eyre. 
Such names are common in some areas, uncommon in others. The syntax of these is well worth further investigation; for example, Merlan (2001) notes the rarity of transitive subjects compared with intransitive subjects and transitive objects in Jawoyn placenames.

\section{CONCLUSION}

We have tried to show that Indigenous placename networks in many areas can be viewed as systematic mnemonics. Within the networks we have suggested that the hunter-gatherer way of life is reflected in the lack of habitation names, and in the lack of placenames formed using relative location indicators such as cardinal points. We have shown also that there are differences in what counts as a significant feature to be named. In terms of the actual names used, we have claimed that commemoration strategies characteristic of introduced placename systems are rarely if ever found.

\section{REFERENCES}

Aklif, Gedda, 1999, Ardiyooloon Bardi Ngaanka: One Arm Point Bardi dictionary. Hall's Creek: Kimberley Language Resource Centre.

Altman, Carol, 2000, What's in a name: a vineyard or a dot on the map? The Australian. 10 February 2000, p.5.

Appleton, Richard and Barbara Appleton, 1992, The Cambridge Dictionary of Australian Places. Cambridge, UK: Cambridge University Press.

Basso, Keith H., 1996, Wisdom Sits in Places: landscape and language among the Western Apache. Albuquerque: University of New Mexico Press.

Berndt, Ronald M. and Catherine H. Berndt, with John E. Stanton, 1993, A World That Was: the Yaraldi of the Murray River and the Lakes, South Australia. Melbourne: Melbourne University Press at the Miegunyah Press.

Cameron, Kenneth, 1996, English Place Names. London: B.T. Batsford.

Carter, Paul, 1988, The Road to Botany Bay. London: Faber and Faber.

Clark, Ian D. and L.L. Harridine, 1990, The Restoration of Jardwadjali and Djab Wurrung Names for Rock Art Sites and Landscape Features in and around the Grampians National Park: a submission to the Victorian Place Names Committee. Paper presented at Koorie Tourism Unit, Victorian Tourism Commission, Melbourne.

Cleland, John Burton, 1952, Meteoric crater — native legend. The South Australian Naturalist 27(2):20.

Cockburn, Rodney, 1908, Nomenclature of South Australia. Adelaide: W.K. Thomas \& Co.

Dixon, R.M.W., 1991, Words of Our Country: stories, place names and vocabulary in Yidiny, the Aboriginal language of the Cairns-Yarrabah region. St Lucia: University of Queensland Press.

Edwards, Dale, c.1996, National Indigenous Place Names Dictionary Project: Final report. 49pp. Canberra: Australian Institute of Aboriginal and Torres Strait Islander Studies. 
In association with the Geographical Names Board of New South Wales and the Department of Employment, Education, Training and Youth Affairs.

Goddard, Cliff, 1985, A Grammar of Yankunytjatjara. Alice Springs: Institute for Aboriginal Development.

Harvey, Mark, 1999, Place names and land--language associations in the Western Top End. Australian Journal of Linguistics 19(2):161-195.

Hawker, James C., 1975, Early Experiences in South Australia. Adelaide: Libraries Board of South Australia.

Henderson, John and David Nash, 1997, Culture and Heritage: indigenous languages. Australia: State of the environment technical papers series (natural and cultural heritage). Department of the Environment, Canberra.

Henderson, John and David Nash, eds. 2002 Language in Native Title. Native Title Research Series, Canberra: Aboriginal Studies Press.

Hercus, Luise A. and Vlad Potezny, 1999, 'Finch' versus 'Finch-water': a study of Aboriginal placenames in South Australia. Records of the South Australian Museum 31(2):165-181.

Kari, James, 1989, Some principles of Alaskan Athabaskan toponymic knowledge. In M.R. Kay and H.M. Hoenigswald, eds, General and Amerindian Ethnolinguistics: in remembrance of Stanley Newman, 129-149. New York: Mouton de Gruyter.

Map sheets:

SA Department of Mines and Energy, n.d. Alinerta 6045 1:100 000 Map sheet. Adelaide.

Joint Operations Graphic, 1984, Billa Kalina, South Australia 1:250 000. Series 1501, SH 53-7, edition 1. Compiled March 1984.

Division of National Mapping, 1981, Dalhousie, South Australia. 1:250 000 Map sheet. SG 53-11, edition 1.

Merlan, Francesca, 2001, Form and context in Jawoyn place-names. In J. Simpson, D. Nash, M. Laughren, P. Austin and B. Alpher, eds, Forty Years On: Ken Hale and Australian languages, 367-383. Canberra: Pacific Linguistics.

Meyer, Heinrich A.E., 1843, Vocabulary of the Language Spoken by the Aborigines of the Southern and Eastern Portions of the Settled Districts of South Australia. Adelaide: James Allen.

Nash, David (in prep.), Ethnocartography: understanding central Australian geographic literacy. Draft, 2 October 1998, 30pp. Presented to Australian Anthropological Society Annual Conference, 2 October 1998.

Petrick, Jose, 1996, The History of Alice Springs through Landmarks and Street Names. Alice Springs, the author.

Stephens, Edward, 1889, The aborigines of Australia. Journal of the Proceedings of the Royal Society of New South Wales 23:476-503.

Strehlow, Theodore G.H., 1971, Songs of Central Australia. Sydney: Angus and Robertson. 
Teichelmann, Christian Gottlob, 1857, Dictionary of the Adelaide dialect. MS. (with double columns). 99pp. Held in South African Public Library.

Teichelmann, Christian Gottlob and Clamor Wilhelm Schürmann, 1840, Outlines of a Grammar, Vocabulary, and Phraseology, of the Aboriginal Language of South Australia, Spoken by the Natives in and for Some Distance around Adelaide. Adelaide: published by the authors, at the native location.

Troy, Jakelin, 1994, The Sydney Language. Canberra: the author.

Tunbridge, Dorothy, 1987, Aboriginal place names [edited address delivered to the Second National Nomenclature Conference (now the Committee for Geographic Names in Australia), 21 August 1986]. Australian Aboriginal Studies 2:2-13.

Walsh, Michael, 1997, The land still speaks? Language and landscape in Aboriginal Australia. In D. Rose and A. Clarke, eds, Tracing Knowledge in North Australian Landscapes: studies in indigenous and settler ecological knowledge systems, 105-119. Darwin: North Australia Research Unit.

Wyatt, William, 1879, Vocabulary of the Adelaide and Encounter Bay tribes, with a few words of that of Rapid Bay. In J.D. Woods, ed., The Native Tribes of South Australia, 169-182. Adelaide: E.S. Wigg \& Son.

Yates, Frances A., 1969, The Art of Memory. Harmondsworth: Penguin Books. 